\title{
Lovastatin increases the proliferation and osteoblastic differentiation of human gingiva-derived stem cells in three-dimensional cultures
}

\author{
BO-BAE KIM, JAE-YONG TAE, YOUNGKYUNG KO and JUN-BEOM PARK
}

\author{
Department of Periodontics, College of Medicine, The Catholic University of Korea, Seoul 06591, Republic of Korea
}

Recieved October 15, 2016; Accepted August 8, 2019

DOI: 10.3892 /etm.2019.7971

\begin{abstract}
Lovastatin is a cholesterol-lowering agent that also has effects of cell proliferation and apoptosis. The present study was performed to evaluate the effects of lovastatin on the proliferation and osteogenic differentiation of three-dimensional cell spheroids formed from human gingiva-derived stem cells (GDSCs) using concave microwells. GDSCs were plated on polydimethylsiloxane-based concave micromolds and grown in the presence of lovastatin at concentrations of 0 , 2 and $6 \mu \mathrm{M}$. The morphology of the cells was viewed under an inverted microscope, and cell viability was determined with Cell Counting kit- 8 on days 2, 7 and 14. Alkaline phosphatase activity assays were performed to evaluate the osteogenic differentiation on days 2 and 8 . Alizarin red-S staining was also used to assess the mineralization of the stem cell spheroids at day 14. The results confirmed that GDSCs formed spheroids in concave microwells. No significant changes were noted with longer incubation time, and no significant differences in cell viability were noted between the three lovastatin groups at each time point. Higher osteogenic differentiation was observed in the $2 \mu \mathrm{M}$ group when compared with the control. Mineralized extracellular deposits were visible after Alizarin red-S staining, and higher mineralization was noted in the 2 and $6 \mu \mathrm{M}$ lovastatin groups when compared with the $0 \mu \mathrm{M}$ control. The relative mineralization values of the 0,2 and $6 \mu \mathrm{M}$ groups on day 14 were $39.0 \pm 9.6,69.3 \pm 6.0$ and $60.9 \pm 7.5$, respectively. This study demonstrated that the application of lovastatin enhanced the osteogenic differentiation of cell spheroids formed from GDSCs. This suggests that combinations of lovastatin and stem cell spheroids may have the potential for use in tissue engineering.
\end{abstract}

Correspondence to: Dr Jun-Beom Park, Department of Periodontics, College of Medicine, The Catholic University of Korea, 222 Banpo-daero, Seocho-gu, Seoul 06591, Republic of Korea

E-mail: jbassoonis@yahoo.co.kr

Key words: cell culture techniques, cell differentiation, cell proliferation, cellular spheroids, gingiva, lovastatin, stem cells

\section{Introduction}

The majority of cell culture experiments are conducted on two-dimensional surfaces, including micro-well plates, tissue culture flasks and Petri dishes, due to the ease and convenience of two-dimensional cultures (1). However, two-dimensional cultures may have limitations for the evaluation of cell and tissue physiology, including the communication between a cell and its matrix and between adjacent cells (2). To overcome these limitations, three-dimensional culture techniques have been applied $(3,4)$. Three-dimensional cultures have advantages including the ability to represent in vivo morphologies and the potential for use in drug discovery with primary and stem cells (5). In a previous study, three-dimensional culture platforms were made using engineered microenvironments, such as highly porous biomimetic scaffolds, which exhibited higher cell differentiation efficiency compared with their two-dimensional counterparts (4). Furthermore, three-dimensional cultures have been shown to support the long-term expansion of nephrogenic progenitor cells (6). Gingiva-derived stem cells (GDSCs) display multipotency with high proliferation characteristics $(7,8)$

Lovastatin is a cholesterol-lowering agent (9); it is involved in regulation of the mevalonate pathway and also affects Akt pathways that are involved in cell proliferation and apoptosis, leading to antiproliferative effect (10). However, the effects of lovastatin on mesenchymal stem cells with three-dimensional cultures have not been well elucidated. Therefore, the purpose of the present study was to evaluate the effects of lovastatin on the proliferation and osteogenic differentiation of human gingiva-derived stem cells (GDSCs) using concave microwells. To the best of the authors' knowledge, this investigation is the first to elucidate the effects of lovastatin on three-dimensional spheroid cultures using mesenchymal stem cells derived from gingiva.

\section{Materials and methods}

Isolation and culture of human GDSCs. Gingival tissues were collected from 75-year-old female undergoing periodontal surgery on August 2013 at Seoul St Mary's Hospital, College of Medicine, The Catholic University of Korea. The design of the study was reviewed and approved by the Institutional Review Board of the Catholic University of Korea, College of 
Medicine (no. KC11SISI0348). Informed consent was obtained from all participants according to the Act on Legal Codes for Biomedical Ethics and Safety and the Declaration of Helsinki. Human GDSCs were isolated and cultivated following the protocol published in the present authors' previous study (7). The gingival tissues were collected and maintained in sterile phosphate-buffered saline (PBS; Welgene, Inc.) containing $100 \mathrm{U} / \mathrm{ml}$ penicillin and $100 \mu \mathrm{g} / \mathrm{ml}$ streptomycin (Sigma-Aldrich; Merck KGaA) at $4^{\circ} \mathrm{C}$. The tissues were de-epithelialized, separated into $1-2-\mathrm{mm}^{2}$ fragments, $0.2 \mu \mathrm{m}$ filtered, and digested in modified in $\alpha$-minimum essential medium ( $\alpha$-MEM; Gibco; Thermo Fisher Scientific, Inc.) containing dispase ( $1 \mathrm{mg} / \mathrm{ml}$; Sigma-Aldrich; Merck KGaA) and collagenase type IV ( $2 \mathrm{mg} / \mathrm{ml}$; Sigma-Aldrich; Merck $\mathrm{KGaA}$ ) at $37^{\circ} \mathrm{C}$ for $30 \mathrm{~min}$. The cell suspension was filtered with a $70-\mu \mathrm{m}$ cell strainer (Falcon; BD Biosciences) and the cells were then incubated at $37^{\circ} \mathrm{C}$ in a humidified incubator with $5 \% \mathrm{CO}_{2}$. After $24 \mathrm{~h}$, the non-adherent cells were washed with PBS.

Formation of spheres and evaluation of cellular morphology. Fig. 1 demonstrates the overview of the present study design. Cells were plated onto silicon elastomer-based concave microwells (StemFIT 3D; MicroFIT) of $600 \mu \mathrm{m}$ diameter at a density of $4 \times 10^{5}$ cells/well and cultured in osteogenic media (StemPro ${ }^{\circledR}$ Osteogenesis Differentiation Kit; Gibco; Thermo Fisher Scientific, Inc.) at $37^{\circ} \mathrm{C}$. The medium was refreshed at 3-day intervals. To examine the effect of lovastatin, the cells were cultured in the presence of lovastatin (Abcam) at final concentrations of 0 (untreated control), 2 and $6 \mu \mathrm{M}$ using dimethyl sulfoxide (DMSO) as the vehicle at plating. The concentrations of lovastatin used in the present study were based on those used in previously published studies (11-14). Equal amounts of DMSO were added to each culture sample to offset the influence of this dissolving vehicle (15). The cells expressed CD44 surface marker and the cell spheroids were positive for SSEA-4 $(7,16)$. The morphology of the microspheres was viewed under an inverted microscope (CKX41; Olympus Corporation) on days 2, 7 and 14 following plating. The diameter of the cell spheroids was measured at each time point.

Determination of cytotoxicity. The cytotoxicity of lovastatin was evaluated on days 2, 7 and 14 with a Cell Counting kit- 8 (CCK-8; Dojindo Molecular Technologies, Inc.) according to the manufacturer's protocol. The absorbance at $450 \mathrm{~nm}$ was measured spectrophotometrically using a microplate reader (BioTek Instruments, Inc.).

Alkaline phosphatase activity assays. Stem cell spheroids grown with osteogenic media (StemPro ${ }^{\circledR}$ Osteogenesis Differentiation kit; Gibco; Thermo Fisher Scientific, Inc.) were obtained on day 2 and 8 . Alkaline phosphatase activity assays were tested using a commercially available kit (K412-500, BioVision, Inc., Milpitas, CA, USA) following the manufacturer's protocol. The cells were resuspended with an assay buffer, sonicated and then centrifuged at 15,000 $\mathrm{x}$ g for $10 \mathrm{~min}$ at $4^{\circ} \mathrm{C}$ to remove insoluble material. The supernatant was mixed with p-nitrophenylphosphate substrate and incubated at $25^{\circ} \mathrm{C}$ for $60 \mathrm{~min}$. The optical density was determined spectrophotometrically at $405 \mathrm{~nm}$.

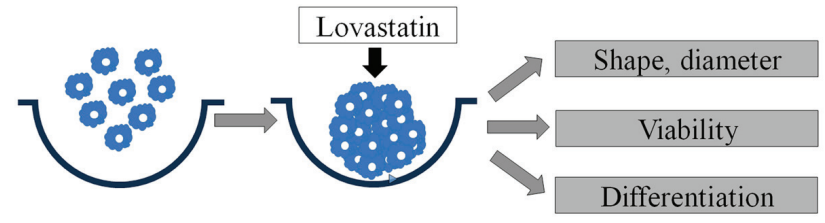

Figure 1. Schematic illustration of the three-dimensional culture and analysis of gingival-derived stem cells.

Alizarin red-S staining. To investigate mineralized nodule formation, cells were grown with osteogenic media (StemPro ${ }^{\circledR}$ Osteogenesis Differentiation kit; Gibco; Thermo Fisher Scientific, Inc.) for 14 days. The cell spheroids were fixed with $4 \%$ paraformaldehyde at room temperature and stained with Alizarin red-S (ScienCell Research Laboratories, Inc.) at room temperature for $30 \mathrm{~min}$. Inverted microscopy (CKX41) was used for evaluation of the stained cells (magnification, $\mathrm{x} 100$ ). The relative value of mineralization was determined by measuring the relative intensity of staining using image processing and analysis software (Image J version 1.8.0; National Institutes of Health).

Statistical analysis. Data are presented as the mean \pm standard deviation with $95 \%$ confidence of intervals (95\% CI). Experiments were performed at least three times. A test of normality was performed with a Shapiro-Wilk test. Two-way analysis of variance (ANOVA) was performed for evaluation of the effects of concentration and time and one-way ANOVA was used to determine the differences among groups, followed by Tukey's post hoc test. The analysis was conducted with SPSS 12 for Windows (SPSS, Inc.). P<0.05 was considered to indicate a statistically significant result.

\section{Results}

Evaluation of cell morphology and cellular viability. GDSCs formed spheroids in the concave microwells. The morphology of the spheroids at day 2 is shown in Fig. 2A-C. The morphologies of the spheroids at days 7 and 14 were similar to those at day 2 (Fig. 2D-I). No obvious changes in morphology were observed as the incubation time increased. The diameters of the spheroids were smallest in the $6 \mu \mathrm{M}$ group at day 2 $(\mathrm{P}<0.001$; Fig. 3$)$. The average diameters of the stem cell spheroids at day 2 were $309.9 \pm 32.7$ (95\% CI: 280.5-339.2), $331.2 \pm 24.0$ (95\% CI: 301.9-360.6) and $231.4 \pm 24.4$ (95\% CI: 202.0-260.7) $\mu \mathrm{m}$ for 0,2 and $6 \mu \mathrm{M}$ lovastatin, respectively $(\mathrm{P}=0.001)$. The average diameters at day 7 were $322.2 \pm 27.1$ (95\% CI: 292.9-351.5), 376.4 \pm 27.9 (95\% CI: 347.1-405.8) and 235.9 \pm 29.6 (95\% CI: 206.6-265.2) $\mu \mathrm{m}$ for 0,2 and $6 \mu \mathrm{M}$ lovastatin, respectively $(\mathrm{P}<0.001)$. The average diameters at day 14 were $275.8 \pm 33.6$ (95\% CI: 246.4-305.1), 346.4 \pm 11.8 (95\% CI: 317.1-375.8) and 317.7 \pm 38.2 (95\% CI: 288.3-347.0) $\mu \mathrm{m}$ for 0,2 and $6 \mu \mathrm{M}$, respectively ( $\mathrm{P}=0.027$; Table I). In general, the diameters of the spheroids were maintained throughout the incubation period.

Cell cytotoxicity. Cell cytotoxicity was measured for the spheroids after culturing for 2,7 and 14 days $(\mathrm{P}=0.035$; Fig. 4). The CCK- 8 assay results for the 0,2 and $6 \mu \mathrm{M}$ groups on 

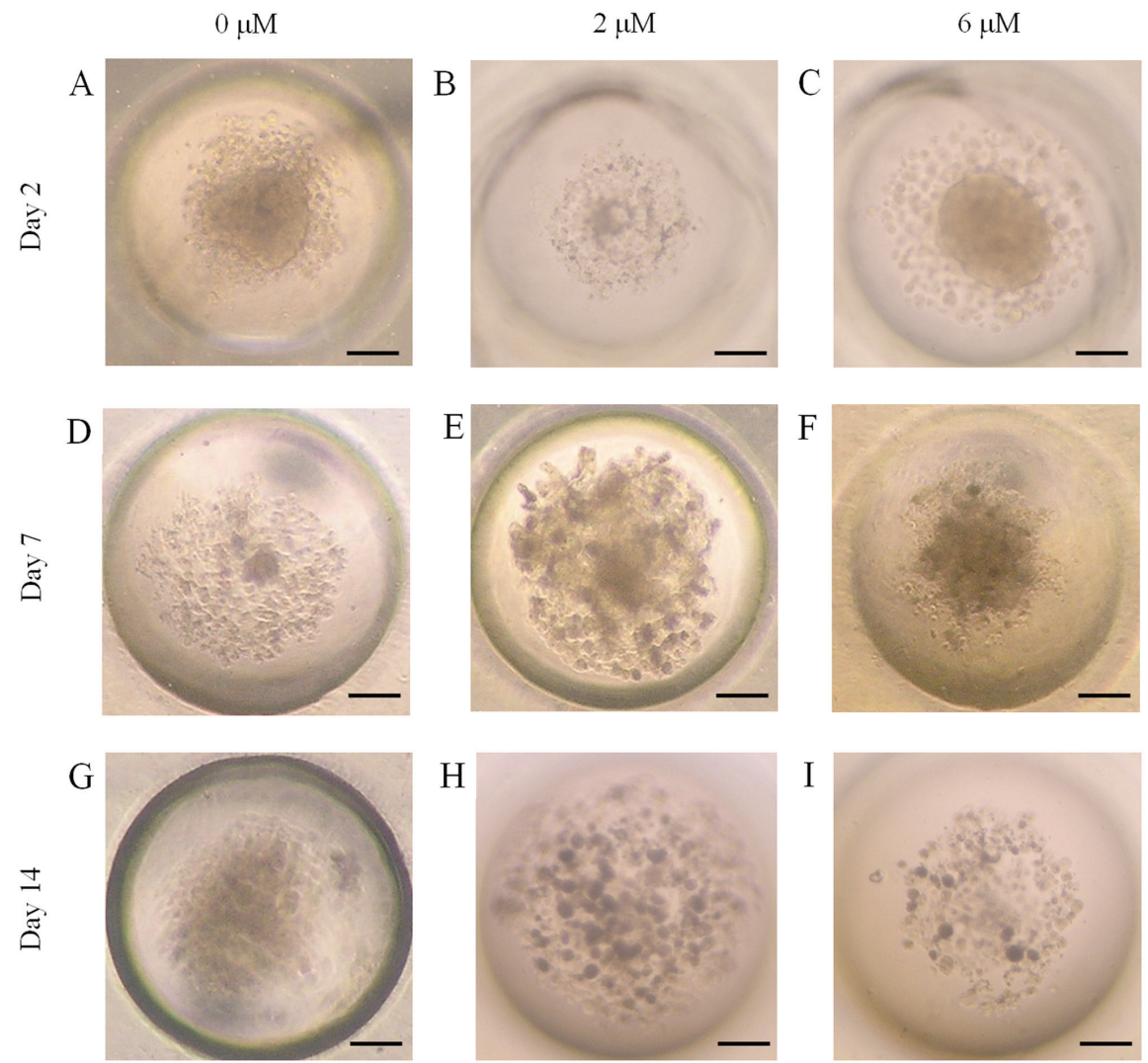

Figure 2. Evaluation of the morphology of the three-dimensional stem cells on days 2,7 and 14. (A) $0 \mu \mathrm{M}$, (B) $2 \mu \mathrm{M}$ and (C) $6 \mu \mathrm{M}$ lovastatin groups on day 2 ; (D) $0 \mu \mathrm{M}$, (E) $2 \mu \mathrm{M}$ and (F) $6 \mu \mathrm{M}$ lovastatin groups on day 7; (G) $0 \mu \mathrm{M}$, (H) $2 \mu \mathrm{M}$ and (I) $6 \mu \mathrm{M}$ lovastatin groups on day 14 . Scale bar, $100 \mu \mathrm{m}$.

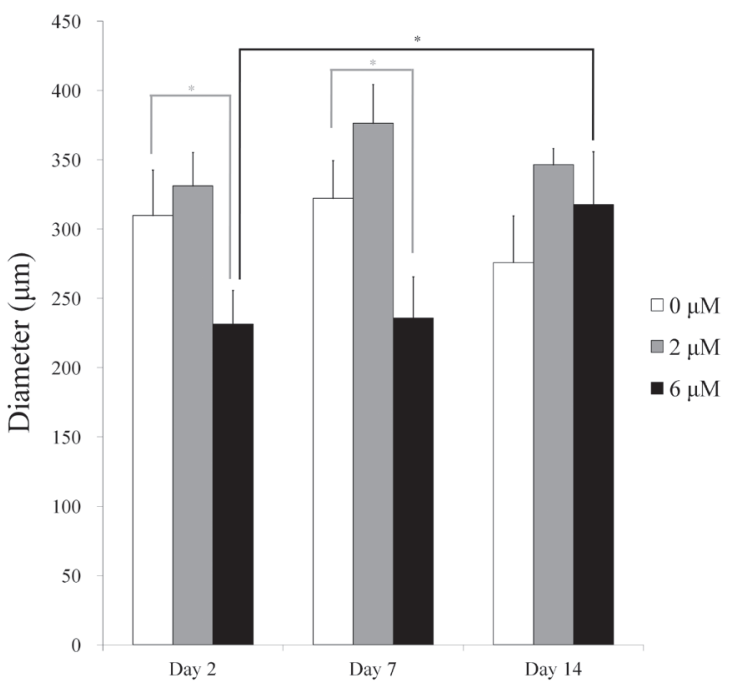

Figure 3. Evaluation of the diameters of the cell spheroids with 0,2 and $6 \mu \mathrm{M}$ lovastatin on days 2,7 and $14 .{ }^{*} \mathrm{P}<0.05$, with comparisons indicated by lines.

day 2 were $0.088 \pm 0.004$ (95\% CI: $0.073,0.104), 0.089 \pm 0.001$ (95\% CI: $0.073,0.105)$ and $0.092 \pm 0.002$ (95\% CI: 0.076 , $0.108)$, respectively $(\mathrm{P}=0.108)$. The $\mathrm{CCK}-8$ assay results at day 7 were $0.104 \pm 0.016$ (95\% CI: $0.088,0.120), 0.117 \pm 0.019$ (95\% CI: $0.101,0.133)$ and $0.110 \pm 0.026$ (95\% CI: 0.094, 0.126) for the 0,2 and $6 \mu \mathrm{M}$ groups, respectively $(\mathrm{P}=0.634)$. No statistically significant differences were detected between the groups at days 2 and 7 ( $P>0.05)$. The CCK- 8 assay values at

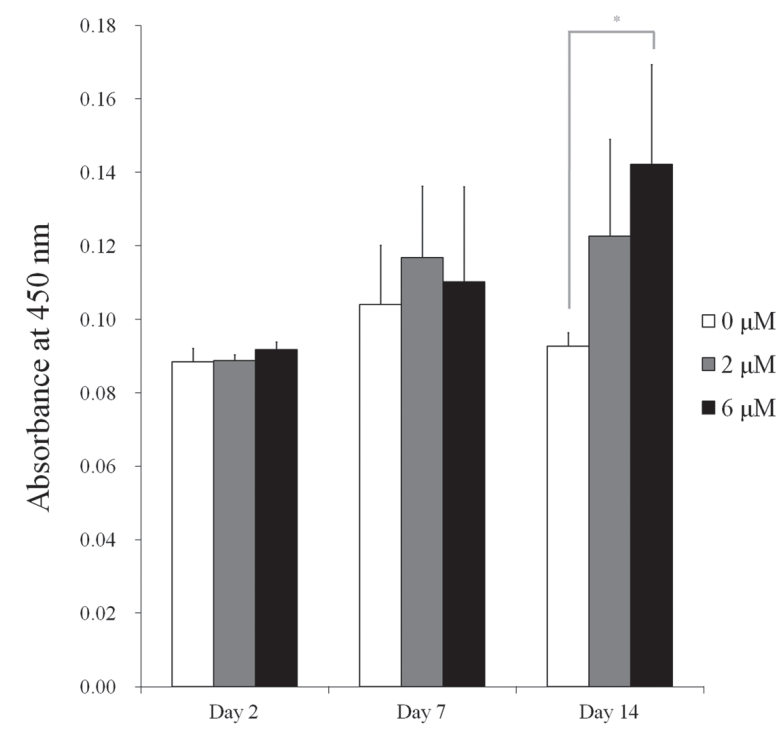

Figure 4. Cellular viability of the cell spheroids with 0,2 and $6 \mu \mathrm{M}$ lovastatin on days 2,7 and 14 . ${ }^{*} \mathrm{P}<0.05$, with comparisons indicated by lines.

day 14 were $0.093 \pm 0.004$ (95\% CI: $0.077,0.108), 0.123 \pm 0.026$ (95\% CI: 0.107, 0.138) and 0.142 \pm 0.027 (95\% CI: 0.126, 0.158) for the 0,2 and $6 \mu \mathrm{M}$ groups, respectively ( $\mathrm{P}=0.012$; Table II).

Alkaline phosphatase activity assay. The results of the alkaline phosphatase activity assay on days 2 and 8 are shown in Fig. 5. The absorbance values at $405 \mathrm{~nm}$ on day 2 for the 
Table I. Cell spheroid diameters $(\mu \mathrm{m})$ for various lovastatin concentrations at different time points.

Lovastatin

\begin{tabular}{lccc}
\cline { 2 - 4 } Time point & \multicolumn{1}{c}{$0 \mu \mathrm{M}$} & $2 \mu \mathrm{M}$ & $6 \mu \mathrm{M}$ \\
\hline Day 2 & $309.9 \pm 32.7(280.5-339.2)$ & $331.2 \pm 24.0(301.9-360.6)$ & $231.4 \pm 24.4(202.0-260.7)$ \\
Day 7 & $322.2 \pm 27.1(292.9-351.5)$ & $376.4 \pm 27.9(347.1-405.8)$ & $235.9 \pm 29.6(206.6-265.2)$ \\
Day 14 & $275.8 \pm 33.6(246.4-305.1)$ & $346.4 \pm 11.8(317.1-375.8)$ & $317.7 \pm 38.2(288.3-347.0)$ \\
\hline
\end{tabular}

Values are presented as the mean \pm SD (95\% confidence interval).

Table II. Cytotoxicity of the cell spheroids for various lovastatin concentrations at different time points.

Lovastatin

\begin{tabular}{lccc}
\cline { 2 - 4 } Time point & $0 \mu \mathrm{M}$ & $2 \mu \mathrm{M}$ & $6 \mu \mathrm{M}$ \\
\hline Day 2 & $0.088 \pm 0.004(0.073,0.104)$ & $0.089 \pm 0.001(0.073,0.105)$ & $0.092 \pm 0.002(0.076,0.108)$ \\
Day 7 & $0.104 \pm 0.016(0.088,0.120)$ & $0.117 \pm 0.019(0.101,0.133)$ & $0.110 \pm 0.026(0.094,0.126)$ \\
Day 14 & $0.093 \pm 0.004(0.077,0.108)$ & $0.123 \pm 0.026(0.107,0.138)$ & $0.142 \pm 0.027(0.126,0.158)$
\end{tabular}

Values are presented as the mean \pm SD $(95 \%$ confidence interval).

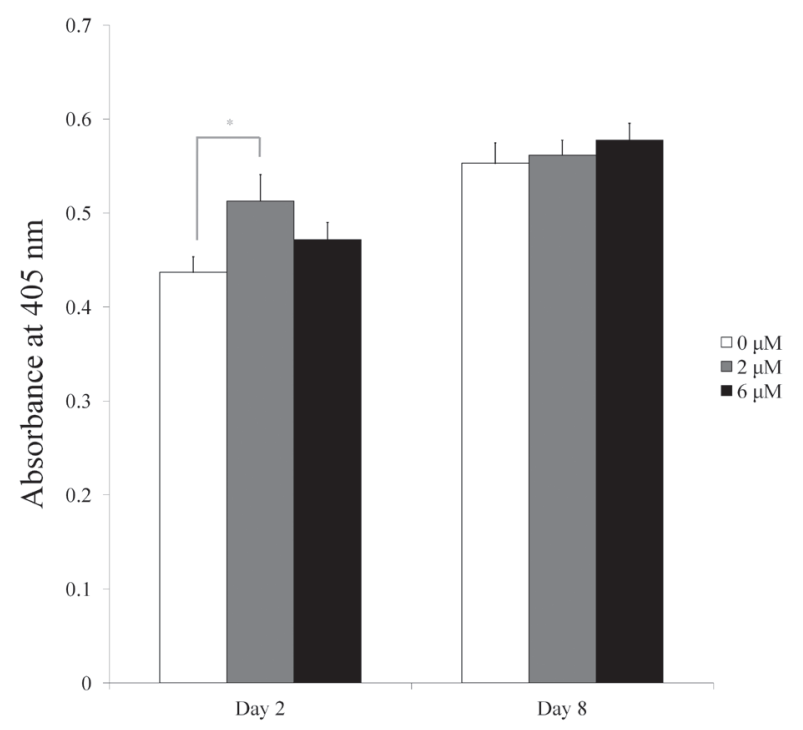

Figure 5. Alkaline phosphatase activity of the cell spheroids on days 2 and 8 . ${ }^{*} \mathrm{P}<0.05$, with comparisons indicated by lines.

0,2 and $6 \mu \mathrm{M}$ groups were $0.437 \pm 0.017,0.513 \pm 0.028$ and $0.472 \pm 0.018$, respectively $(\mathrm{P}<0.05)$. The value for the $2 \mu \mathrm{M}$ group was significantly higher compared with that of the $0 \mu \mathrm{M}$ group $(\mathrm{P}<0.05)$. The absorbance values at $405 \mathrm{~nm}$ on day 8 for the 0,2 and $6 \mu \mathrm{M}$ groups were $0.553 \pm 0.022,0.562 \pm 0.016$ and $0.578 \pm 0.018$, respectively $(\mathrm{P}>0.05)$.

Mineralization assay. Mineralized extracellular deposits were observed after Alizarin red-S staining on day 14 (Fig. 6). Higher mineralization was observed in the 2 and $6 \mu \mathrm{M}$ groups when compared with the $0 \mu \mathrm{M}$ control (Fig. 7; $\mathrm{P}<0.05$ ). The relative values of the 0,2 and $6 \mu \mathrm{M}$ groups on day 14 were

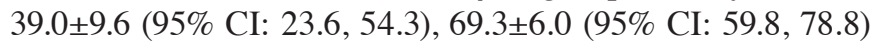
and $60.9 \pm 7.5$ (95\% CI: 49.0, 72.8), respectively $(\mathrm{P}=0.001)$.

\section{Discussion}

The present study clearly demonstrates that lovastatin at the tested concentrations did not adversely affect the viability of the stem cell spheroids, and increased their osteogenic differentiation.

Statins are drugs that are widely used for lowering serum cholesterol, but have also been shown to enhance new bone formation in vitro and in rodents in previous studies (15,17-19). The locally delivery of lovastatin using biodegradable polymer nanobeads of poly(lactic-co-glycolide acid) has been found to improve fracture healing in rats (20). In another study, lovastatin-loaded biodegradable polyurethanes exhibited sustained release of biologically active lovastatin, and the released lovastatin significantly enhanced the osteogenic differentiation of osteoblastic cells in vitro (21). Similarly, the present study using cell spheroids without scaffold confirmed the increased osteogenic differentiation of stem cells when cultured with 2-6 $\mu \mathrm{M}$ lovastatin, suggesting a potential application in therapeutic agents for bone formation.

In a previous study, statins impaired the survival of primary human mesenchymal progenitor cells via mevalonate depletion, nuclear factor $\kappa \mathrm{B}$ signaling and B-cell lymphoma 2/adenovirus E1B $19 \mathrm{kDa}$ protein-interacting protein 3 when 1 and $10 \mu \mathrm{M}$ simvastatin or atorvastatin was used (22). In another study, exposure to simvastatin $(0-20 \mu \mathrm{M})$ induced a reduction in sphere-forming capacity and cell viability, 

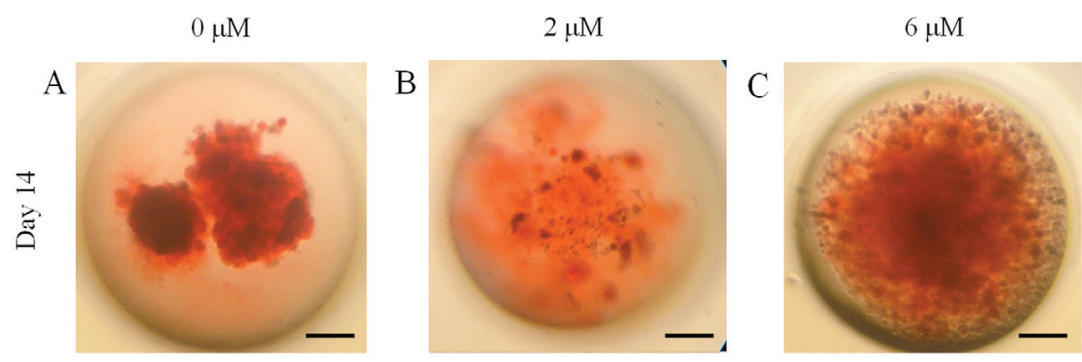

Figure 6. Representative images of Alizarin red-S staining on day 14. (A) $0 \mu \mathrm{M}$, (B) $2 \mu \mathrm{M}$ and (C) $6 \mu \mathrm{M}$ lovastatin groups on day 14 . Scale bar, $100 \mu \mathrm{m}$.

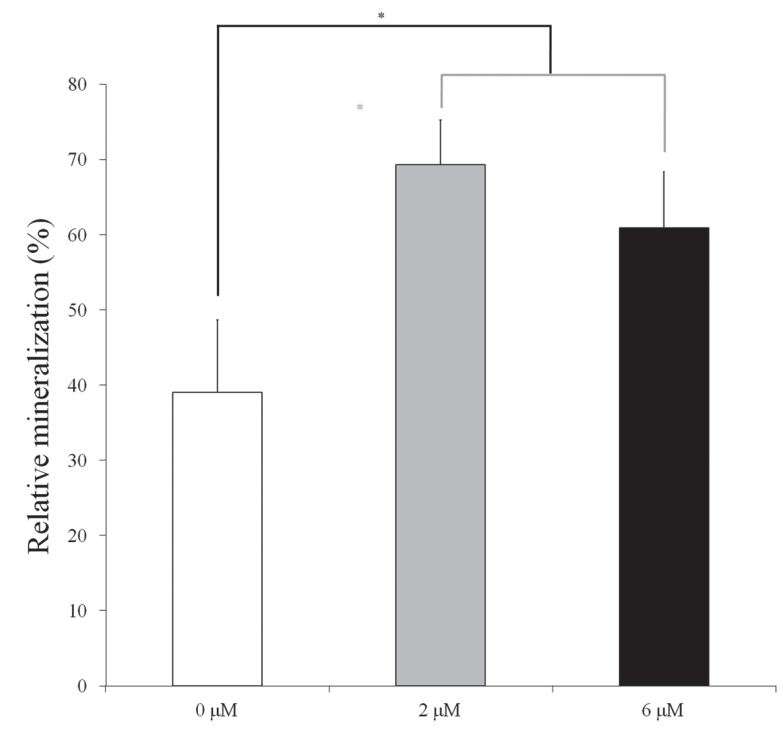

Figure 7. Quantitative results of the mineralization assay. "P<0.05, with comparisons indicated by lines.

accompanied by a concentration- and time-dependent increase in caspase-3/7 activity (23). Conversely, lovastatin (0.01-1 $\mu \mathrm{M})$ was found to prevent mesenchymal stem cells from undergoing hypoxia/serum deprivation-induced apoptosis through inhibition of the mitochondrial apoptotic pathway, leading to attenuation of caspase-3 activation (24). In an in vitro study, simvastatin inhibited mesenchymal stem cell apoptosis and increased vascular endothelial growth factor, and combined treatment with simvastatin and mesenchymal stem cells induced a significant improvement in blood reperfusion and a notable increase in capillary density (25).

Mesenchymal stem cells have been applied in tissue engineering, for tissues including bone, cartilage, fat and other connective tissue (26). Mesenchymal stem cells have been characterized from a variety of dental-related tissues, including periodontal ligaments, papilla, follicle, dental pulp of exfoliated deciduous and adult teeth, and the maxillary sinus membrane, which represent rich sources of mesenchymal stem cells $(27,28)$. These stem cells have the capacity for self-renewal and multi-lineage differentiation, including osteogenic, chondrogenic and adipogenic differentiation (29). In addition, dental stem cells display several advantages, including a high proliferation rate, high viability and easy induction to distinct cell lineages (27). Moreover, human GDSCs can be harvested during routine practice under local anesthesia and may be considered an excellent source for tissue-engineering purposes (7). Further studies are warranted to evaluate the effects of combination therapy using animal models.

The present study demonstrated that cell spheroids formed from stem cells combined with the application of lovastatin at the tested concentrations had enhanced osteogenic differentiation capability. Therefore, combinations of lovastatin and stem cell spheroids may potentially be useful for tissue engineering purposes.

\section{Acknowledgements}

Not applicable.

\section{Funding}

The present study was supported by a grant from Catholic Institute of Cell Therapy in 2019, the Research Fund of Seoul St. Mary's Hospital, The Catholic University of Korea and the Basic Science Research Program through the National Research Foundation of Korea (NRF) funded by the Ministry of Science, Information and Communication Technology \& Future Planning (grant no. NRF-2017R1A1A1A05001307).

\section{Availability of data and materials}

All data generated or analyzed during the present study are included in the published article.

\section{Authors' contributions}

BK, JT, YK and JP designed the study, performed the experiments, were responsible for data collection and analysis, and participated in drafting the manuscript. All the authors read and approved the final version of the manuscript.

\section{Ethics approval and consent to participate}

All procedures involving human participants were in accordance with the 1964 Helsinki Declaration and its later amendments or comparable ethical standards, and were approved by the Institutional Review Board of the Catholic University of Korea, College of Medicine (no. KC11SISI0348). Informed consent was obtained from the participant.

\section{Patient consent for publication}

Not applicable. 


\section{Competing interests}

The authors declare that they have no competing interests.

\section{References}

1. Lee J, Cuddihy MJ and Kotov NA: Three-dimensional cell culture matrices: State of the art. Tissue Eng Part B Rev 14: 61-86, 2008

2. Haycock JW: 3D cell culture: A review of current approaches and techniques. Methods Mol Biol 695: 1-15, 2011.

3. Lee SI, Yeo SI, Kim BB, Ko Y and Park JB: Formation of size-controllable spheroids using gingiva-derived stem cells and concave microwells: Morphology and viability tests. Biomed Rep 4: 97-101, 2016.

4. Wang W, Itaka K, Ohba S, Nishiyama N, Chung UI, Yamasaki Y and Kataoka K: 3D spheroid culture system on micropatterned substrates for improved differentiation efficiency of multipotent mesenchymal stem cells. Biomaterials 30: 2705-2715, 2009.

5. Justice BA, Badr NA and Felder RA: 3D cell culture opens new dimensions in cell-based assays. Drug Discov Today 14: 102-107, 2009.

6. Li Z, Araoka T, Wu J, Liao HK, Li M, Lazo M, Zhou B, Sui Y, Wu MZ, Tamura I, et al: 3D culture supports long-term expansion of mouse and human nephrogenic progenitors. Cell Stem Cell 19: 516-529. 2016.

7. Jin SH, Lee JE, Yun JH, Kim I, Ko Y and Park JB: Isolation and characterization of human mesenchymal stem cells from gingival connective tissue. J Periodontal Res 50: 461-467, 2015.

8. Tae JY, Lee H, Lee H, Ko Y and Park JB: Osteogenic potential of cell spheroids composed of varying ratios of gingiva-derived and bone marrow stem cells using concave microwells. Exp Ther Med 16: 2287-2294, 2018

9. Wajid N, Anwar SS, Ali F, Zahoor M, Hamid N, Aslam MM and Ali A: Medicinal significance of lovastatin. Int J Pharm Sci Res 6: 971-977, 2015.

10. Thibault A, Samid D, Tompkins AC, Figg WD, Cooper MR, Hohl RJ, Trepel J, Liang B, Patronas N, Venzon DJ, et al: Phase I study of lovastatin, an inhibitor of the mevalonate pathway, in patients with cancer. Clin Cancer Res 2: 483-491, 1996.

11. Maeda T, Kawane T and Horiuchi N: Statins augment vascular endothelial growth factor expression in osteoblastic cells via inhibition of protein prenylation. Endocrinology 144: 681-692, 2003.

12. Lee H, Lee H, Na CB and Park JB: Effects of simvastatin on the viability and secretion of vascular endothelial growth factor of cell spheroids cultured in growth media. Implant Dent 27: 480-487, 2018

13. Maeda T, Matsunuma A, Kurahashi I, Yanagawa T, Yoshida H and Horiuchi N: Induction of osteoblast differentiation indices by statins in MC3T3-E1 cells. J Cell Biochem 92: 458-471, 2004.

14. Yang SH, Lin HY, Changou CA, Chen CH, Liu YR, Wang J, Jiang $\mathrm{X}$, Luh F and Yen Y: Integrin $\beta 3$ and LKB1 are independently involved in the inhibition of proliferation by lovastatin in human intrahepatic cholangiocarcinoma. Oncotarget 7: 362-373, 2016.

15. Park JB, Zhang H, Lin CY, Chung CP, Byun Y, Park YS and Yang VC: Simvastatin maintains osteoblastic viability while promoting differentiation by partially regulating the expressions of estrogen receptors $\alpha$. J Surg Res 174: 278-283, 2012.
16. Lee SI, Ko Y and Park JB: Evaluation of the maintenance of stemness, viability, and differentiation potential of gingiva-derived stem-cell spheroids. Exp Ther Med 13: 1757-1764: 2017.

17. Mundy G, Garrett R, Harris S, Chan J, Chen D, Rossini G, Boyce B, Zhao M and Gutierrez G: Stimulation of bone formation in vitro and in rodents by statins. Science 286: 1946-1949, 1999.

18. Park JB: The use of simvastatin in bone regeneration. Med Oral Patol Oral Cir Bucal 14: e485-e488, 2009.

19. Park JB: Combination of simvastatin and bone morphogenetic protein-2 enhances the differentiation of osteoblasts by regulating the expression of phospho-Smad1/5/8. Exp Ther Med 4: 303-306, 2012

20. Garrett IR, Gutierrez GE, Rossini G, Nyman J, McCluskey B, Flores A and Mundy GR: Locally delivered lovastatin nanoparticles enhance fracture healing in rats. J Orthop Res 25: 1351-1357, 2007.

21. Yoshii T, Hafeman AE, Nyman JS, Esparza JM, Shinomiya K, Spengler DM, Mundy GR, Gutierrez GE and Guelcher SA: A sustained release of lovastatin from biodegradable, elastomeric polyurethane scaffolds for enhanced bone regeneration. Tissue Eng Part A 16: 2369-2379, 2010.

22. Li Y, Müller AL, Ngo MA, Sran K, Bellan D, Arora RC, Kirshenbaum LA and Freed DH: Statins impair survival of primary human mesenchymal progenitor cells via mevalonate depletion, NF- $\kappa \mathrm{B}$ signaling, and Bnip3. J Cardiovasc Transl Res 8: 96-105, 2015.

23. Torres CG, Olivares A and Stoore C: Simvastatin exhibits antiproliferative effects on spheres derived from canine mammary carcinoma cells. Oncol Rep 33: 2235-2244, 2015.

24. Xu R, Chen J, Cong X, Hu S and Chen X: Lovastatin protects mesenchymal stem cells against hypoxia- and serum deprivation-induced apoptosis by activation of PI3K/Akt and ERK1/2. J Cell Biochem 103: 256-269, 2008.

25. Li Y, Zhang D, Zhang Y, He G and Zhang F: Augmentation of neovascularization in murine hindlimb ischemia by combined therapy with simvastatin and bone marrow-derived mesenchymal stem cells transplantation. J Biomed Sci 17: 75, 2010.

26. Jeong SH, Lee JE, Kim BB, Ko Y and Park JB: Evaluation of the effects of cimicifugae rhizoma on the morphology and viability of mesenchymal stem cells. Exp Ther Med 10: 629-634, 2015.

27. Lei M, Li K, Li B, Gao LN, Chen FM and Jin Y: Mesenchymal stem cell characteristics of dental pulp and periodontal ligament stem cells after in vivo transplantation. Biomaterials 35 : 6332-6343, 2014.

28. Kim JH, Ko SY, Lee JH, Kim DH and Yun JH: Evaluation of the periodontal regenerative properties of patterned human periodontal ligament stem cell sheets. J Periodontal Implant Sci 47: 402-415, 2017.

29. Seo BM, Miura M, Gronthos S, Bartold PM, Batouli S, Brahim J, Young M, Robey PG, Wang CY and Shi S: Investigation of multipotent postnatal stem cells from human periodontal ligament. Lancet 364: 149-155, 2004.

This work is licensed under a Creative Commons Attribution-NonCommercial-NoDerivatives 4.0 International (CC BY-NC-ND 4.0) License. 